\title{
Occurrence of Black Scurf Disease of Potato in Multan (Punjab) Alongwith Its in vitro Chemical and Biotic Elicitor Mediated Management
}

\author{
Owais Malik ${ }^{1}$, Sobia Chohan ${ }^{2} \&$ Syed Atif Hasan Naqvi ${ }^{2}$ \\ ${ }^{1}$ Department of Plant Pathology, Faculty of agricultural Sciences and Technology, Bahauddin Zakariaya \\ University, Multan, Pakistan \\ Correspondence: Syed Atif Hasan Naqvi, Owais Malik, Department of Plant Pathology, Faculty of Agricultural \\ Sciences and Technology, Bahauddin Zakariaya University, Multan, (60000), Pakistan. E-mail: \\ atifhasanshah@hotmail.com; ovjasmalik@yahoo.com
}

Received: May 26, 2014 Accepted: July 6, 2014 Online Published: August 15, 2014

doi:10.5539/jas.v6n9p134 URL: http://dx.doi.org/10.5539/jas.v6n9p134

\begin{abstract}
Black scurf disease of potato, caused by fungus Rhizoctonia solani, is the most common and one of the oldest diseases of potato affecting stem and stolons. In recent years, the disease is reportedly present in the fields of potato in Pakistan especially in Punjab. Survey of different locations viz. Narangaabad, Band Bosan, Kaian Pur, Kotla Abdul-Fateh and Dhillun was conducted to assess the prevalence of disease in Multan region. Maximum disease incidence and severity of $95.00 \%$ and 3.1 rating, was recorded in Kotla Abdul-Fateh respectively. Sclerotial pieces showing characteristic symptoms of black scurf were detached from tuber surface and the fungus was isolated on potato dextrose agar medium. For in-vitro chemical and biotic elicitor testing, three different fungicides viz., Monceren, Topsin-M, and Triton were evaluated using poisoned food technique and antagonistic effect of two accessions of Triochoderma spp. viz. Trichoderma harzianum and Trichoderma viridae was determined against the sensitivity of fungus. Triton was found to be superior at all concentrations in inhibiting the radial mycelial growth of the fungus followed by Topsin-M and Monceren. Satisfactory results were obtained by the antagonistic effect of Trichoderma harzinaum and Trichoderma viridae with $70.00 \%$ and $66.00 \%$ respectively under in-vitro conditions. Although the fungicide chemistries exclusively control the fungus yet the evaluation of bioagents also remained prolific towards antagonism against Rhizoctonia solani. These investigations provide fresh information on the current status of black scurf disease of potato in fields of Multan and regarding the biochemical management against Rhizoctonia solani under in-vitro conditions and serve as a guide for the future prospects against this holistic disease.
\end{abstract}

Keywords: Rhizoctonia solani, black scurf, chemical, Trichoderma spp.

\section{Introduction}

Potato (Solanum tuberosum L.) is an annual, herbaceous and dicotyledonous plant belonging to genus Solanum and family Solanaceae, a major vegetable crop of Pakistan, grown on an area of 185.1 thousand hectares with an annual production of 4104.4 thousand tonnes (Anonymous, 2013). Potato belongs to one botanical specie Solanum tuberosum but it comprises of thousands of varieties that vary in their characteristics. Potato's origin is from South America Andes. Chile and Peru fight over its origin (Anonymous, 2008). Haq et al. (2008) reported that half of population of Pakistan is at threshold level of food insecurity because of shortage and surge in prices of food items according to World Food Program. Researchers at International Potato Center have recommended that the emergent dilemma of food supply due to rise in prices and production of crops intended for bio-fuel rather than foodstuff could be lessened by an increase in potato cultivation (CIP, 2008). Potato crop is having serious and major pathological threats in Pakistan and during recent years, soil-borne and seed-borne diseases have turned out to be a major threat to this crop in Pakistan (Ahmad et al., 1995).

Among the various fungal diseases of potato crop, black scurf disease of potato caused by, Rhizoctonia solani, (Ahmed et al., 1995; Khan et al., 1995) is the serious and most commonly observed disease with the characteristic symptoms of black scurf (dark brown to black colored hard masses of sclerotia, irregularly shaped and superficial, varying from small, flat, barely detectable blotches to large and raised lumps adhering tightly to 
the skin) on tubers and stem canker are the result of Rhizoctonia disease complex in potato (Tsror, 2010). Black scurf disease increases gradually as level of inoculum increases and sclerotia may develop on tuber surface even under primary low inoculum level, resultantly the control through fungicidal chemistries is not always useful especially when levels of initial inoculum are high (Tsror \& Peretz 2005; Kyritsis \& Wale, 2002).

Idrees et al. (2009) evaluated Topsin-M, Score and copper oxychloride as a dressing on potato tuber against black scurf of potato and found Topsin-M to be the best fungicide against the fungus. Rauf et al. (2007a) reported Monceren a good fungicide for management of black scurf disease of potato, which decreased stem girdling, sprout killing, stem canker, and black scurf prevalence among the three tested fungicides viz. Dithane M-45, Benlate and Monceren. Diseased tubers treatment with Monceren greatly abridged the sclerotial viability during in vitro experiments (Campion et al., 2003; Wicks et al., 1995). Keeping in view the economic potential of the crop, present investigations were aimed to determine the disease incidence, severity, chemical and biotic elicitor mediated management to tackle with the disease.

\section{Material and Methods}

\subsection{Study Area}

The study was carried out in March-April (2012) at five distinct potato grown locations in Multan (Punjab), viz Narangaabad located at $\left(30.264^{\circ} \mathrm{N}\right.$ and $\left.71.488^{\circ} \mathrm{E}\right)$, Band Bosan $\left(30.268^{\circ} \mathrm{N}\right.$ and $\left.71.495^{\circ} \mathrm{E}\right)$, Kaian Pur $\left(30.261^{\circ}\right.$ $\mathrm{N}$ and $\left.70.486^{\circ} \mathrm{E}\right)$, Kotla Abdul-Fateh $\left(30.259^{\circ} \mathrm{N}\right.$ and $\left.70.484^{\circ} \mathrm{E}\right)$ and Dhillun $\left(30.265^{\circ} \mathrm{N}\right.$ and $\left.71.490^{\circ} \mathrm{E}\right)$. During survey, diagonal $(\mathrm{X})$ method was adopted for collection of samples and potato tubers weighing $5-6 \mathrm{~kg}$ were taken at random from the harvesting plants in the field.

\subsection{Disease Incidence}

20 potatoes were randomly selected from each surveyed location to determine disease incidence using formula proposed by Ahmed et al. (1995)

$$
\text { Disease Incidence }=\frac{\text { No. of tubers infected }}{\text { Total Tubers Observed }} \times 100
$$

\subsection{Disease Severity}

Disease severity was determined by using 0-5 disease severity grades based on percent tuber surface showing disease symptoms (Table 1), (Ahmed et al., 1995).

Table 1. Disease severity scale for the assessment of black scruf of potato under field conditions

\begin{tabular}{cc}
\hline Disease Severity Grades & Percentage of Disease \\
\hline 0 & No disease symptoms \\
1 & $<1 \%$ tuber surface affected \\
2 & 1 to $10 \%$ tuber surface affected \\
3 & 11 to $20 \%$ tuber surface affected \\
4 & $21-50 \%$ tuber surface affected. \\
5 & $>50 \%$ tuber surface affected \\
\hline
\end{tabular}

\subsection{Isolation, Purification and Identification of Rhizoctonia solani}

The infected potato tubers showing sclerotial masses were washed under tap water. Five sclerotial pieces, each of 3 to $5 \mathrm{~mm}$ length, were then excised from tubers with sterile forceps. Disinfection was done in $1 \%$ sodium hypochlorite solution for two minutes. Sclerotial pieces were dried on sterilized blotting papers and placed on 9 $\mathrm{cm}$ Pyrex glass Petri dishes containing potato dextrose agar medium. The plates were completely randomized in incubator at $25{ }^{\circ} \mathrm{C}$ with the illumination of 600 Lux. The tested material culture (Rhizoctonia solani) was multiplied on PDA for experimentation. The pathogen was identified on basis of morphological characteristics under the compound microscope (Parmeter, 1970; Sneh et al., 1991; Bhuiyan, 1994; Tredway \& Burpee, 2001).

\subsection{Efficacy of Three Fungicides for Management of Rhizoctonia solani}

Poisoned food technique (Dhingra \& Sinclair, 1985) was used to determine the efficacy of the three fungicides 
viz. Monceren at the rate of $0.6,0.3$, and $0.9 \mathrm{ml}(\mathrm{v} / \mathrm{v})$, Topsin-M at the rate of $0.4,0.2$ and $0.6 \mathrm{~g}(\mathrm{w} / \mathrm{v})$ and Triton at the rate of $1.2,0.9$, and $1.5 \mathrm{ml}(\mathrm{v} / \mathrm{v})$ at $1 \mathrm{~kg}$ seed treatment dose compared with the recommended and standard field doses (Table 2). The tested concentrations were amended in Petri dishes containing potato dextrose agar medium. Four replicated plates were used for each concentration of every fungicide with completely randomized design (CRD) and four replicated plates received no fungicide served as control. Incubation was done at $28{ }^{\circ} \mathrm{C}$ and data of mycelial radial growth was recorded after seven days when the growth of control plates completely covered the petri dishes. Percent inhibition of mycelial growth was determined based on colony diameter on control plate using the formula (Sunder et al., 1995).

$$
\text { P. I. }=\frac{\mathrm{X}-\mathrm{Y}}{\mathrm{X}} \times 100
$$

Where, P. I. = Percent Inhibition; $\mathrm{X}=$ Growth (of Rhizoctonia) in control plate; $\mathrm{Y}=$ Growth (of Rhizoctonia) in fungicide-treated plate.

Table 2. Chemicals used for in-vitro evaluation against Rhizoctonia solani

\begin{tabular}{cccccc}
\hline Trade name & Common name of a.i.* & Formulation & Percent a.i.* & Recommended field dose & Company name \\
\hline Monceren & Pencycuron & FS & 250 & $60 \mathrm{ml} / 100 \mathrm{~kg}$ seed & Bayer Crop Sciences \\
Topsin-M & Thiophanate- -methyl & WP & 70 & $200 \mathrm{~g} / 100 \mathrm{~kg}$ seed & Arysta Life Sciences \\
Triton & Validamycin & SL & 10 & $120 \mathrm{ml} / 100 \mathrm{~kg}$ seed & AgPharma, Kanzo \\
\hline
\end{tabular}

*a.i.= Active ingredient.

\subsection{Biological Control of Rhizoctonia solani Through Antagnostic Fungi}

Antagnostic effect of Trichoderma species viz. Trichoderma harzianum and Trichoderma viridae was investigated against Rhizoctonia solani on potato dextrose agar medium by dual culture technique (Morton \& Strouble, 1955; Skidmore \& Dickinson, 1976). Each treatment was replicated four times in completely randomized design. The petri dishes received only mycelial discs of tested pathogen the Rhizoctonia solani served as control. The petri dishes were incubated at $25{ }^{\circ} \mathrm{C}$ temperature until the radial mycelial growth of the tested pathogen; Rhizoctonia solani covered the whole control plate. Percent inhibition of radial growth was calculated in relation to growth of control plate by the formula (Edington et al., 1971).

$$
\mathrm{L}=[(\mathrm{C}-\mathrm{T}) / \mathrm{C}] \times 100
$$

Where, $\mathrm{L}=$ Inhibition of radial mycelial growth; $\mathrm{C}=$ Pathogen Radial growth measurement in control; $\mathrm{T}=$ Pathogen Radial growth in the presence of Trichoderma spp.

\subsection{Statistical Analysis}

The data of mycelial radial growth fungus was analyzed for analysis of variance (ANOVA) using SAS (statistical analysis system version 9.1). Treatment means were compared by least significant difference (LSD) test at $(\mathrm{P} \leq$ $0.05)$.

\section{Results}

Surveyed results indicated the prevalence of disease at all visited areas. The aboveground parts of potato plants showed aerial tubers, rolling of leaves and chlorosis before harvesting while the most obvious symptoms of the black scurf were observed as sclerotial masses on tubers after harvesting of crop. 


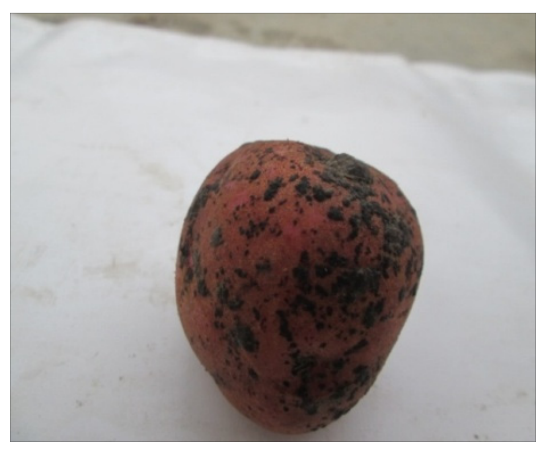

Figure 1. Sclerotial masses on tubers

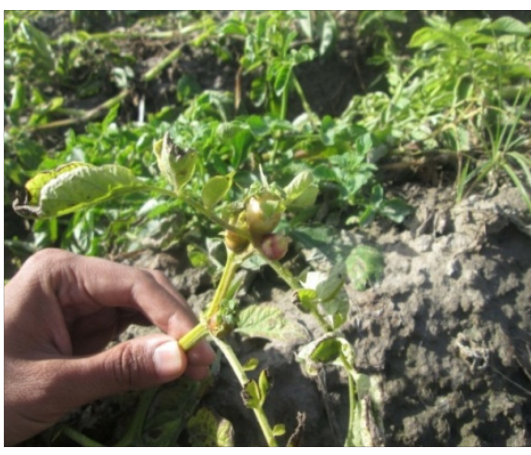

Figure 2. Aerial tubers

Maximum disease incidence (95\%) was recorded at Kotla Abdul Fateh and Dhillun followed by Narangabaad $(65 \%)$ and minimum disease incidence $(45 \%)$ was observed at Band Bosan.

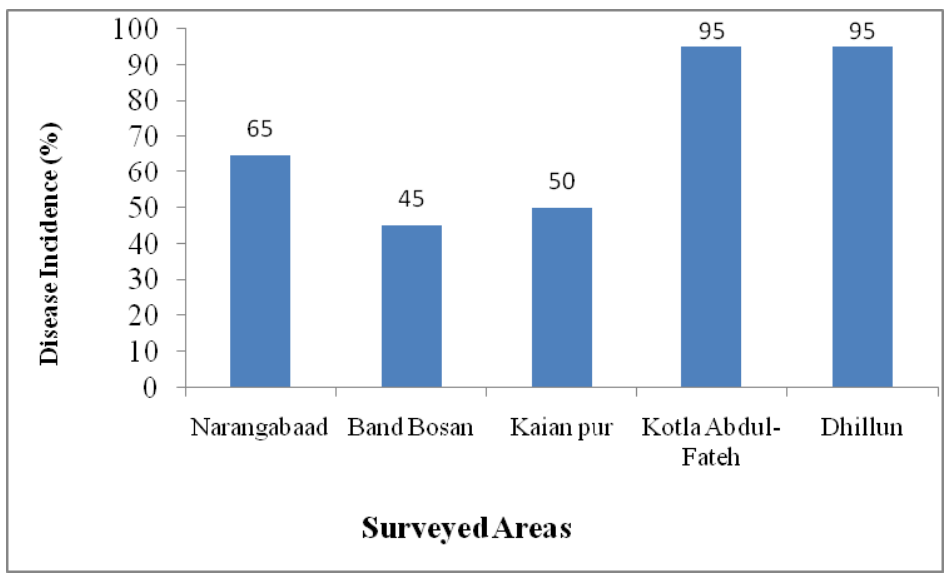

Figure 3. Disease incidence (\%) of black scurf of potato in various surveyed locations of Multan

At individual localities, the highest mean disease severity of 3.1 was calculated at Kotla Abdul-Fateh followed by 2.9 at Dhillun. The minimum disease severity of 0.5 was found at Band Bosan.

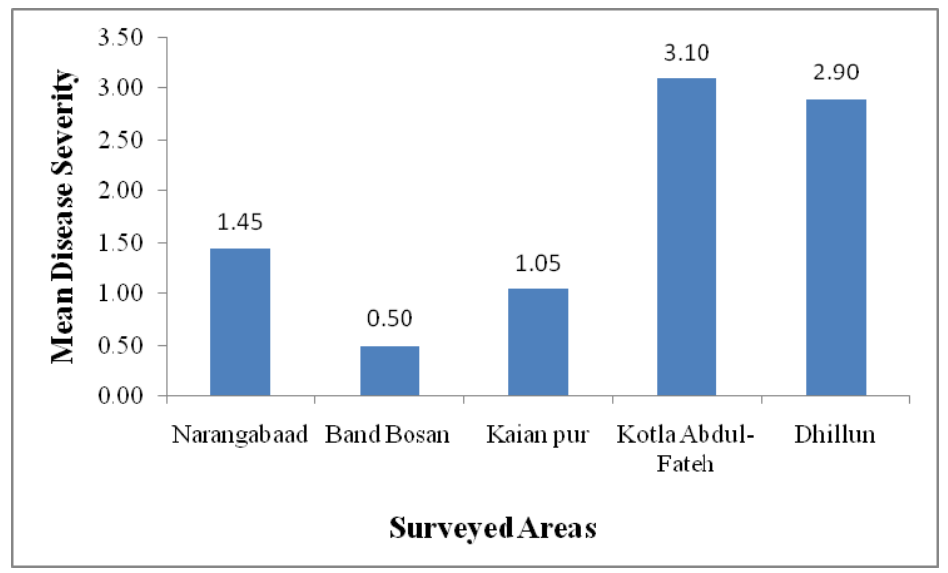

Figure 4. Mean disease severity of black scurf of potato in various surveyed locations of Multan

The Rhizoctonia solani was initially identified by the presence of thread-like whitish mycelial growth, which gradually turned to dark brown followed by production of sclerotia on the culture that seemed to be submerged in the agar plates. Large aggregates of sclerotia were spherical and irregularly shaped. Anastomosis showed septate hyphae to be branched at $90{ }^{\circ} \mathrm{C}$ to the main hypha with slight tapering at branch origin with no sexual 
spores.

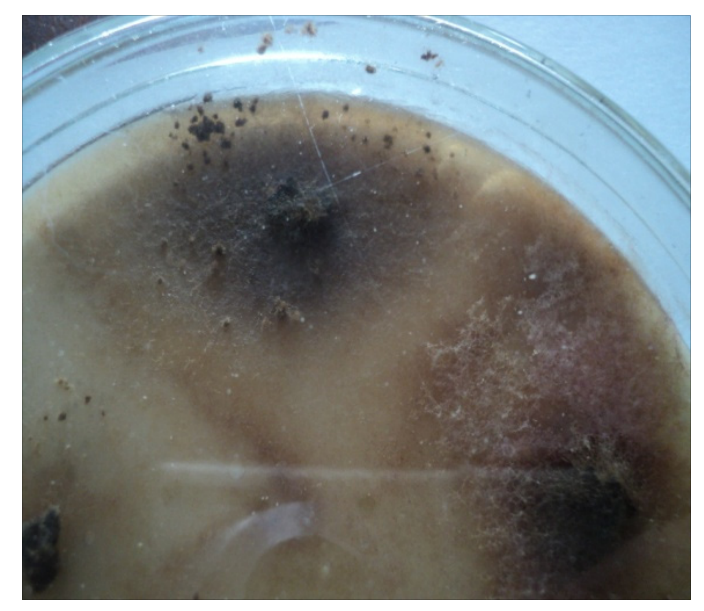

Figure 5. Sclerotia formation of mycelium of Rhizoctonia solani

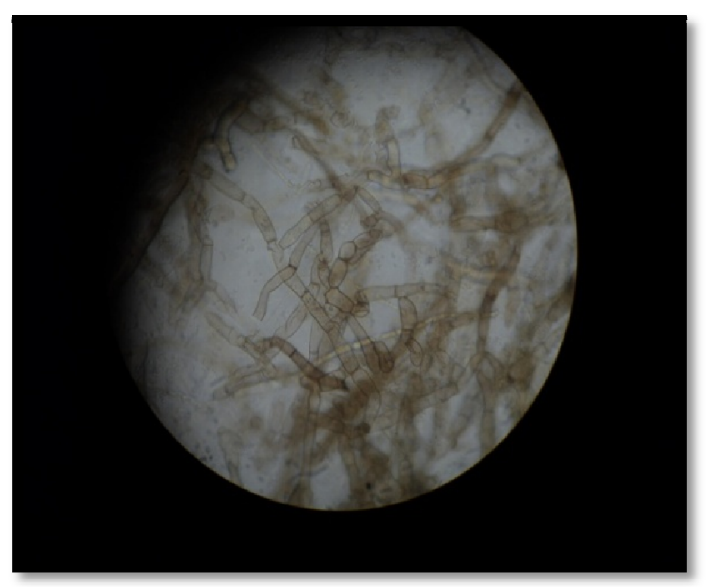

Figure 6. Microscopic view of septate Rhizoctonia solani on potato dextrose agar media

The effect of three fungicides was tested by poisoned food technique on the inhibition of mycelial growth of Rhizoctonia solani after seven days. Topsin $\mathrm{M}$ and Triton were found to be most effective fungicide against Rhizoctonia solani at all concentrations.

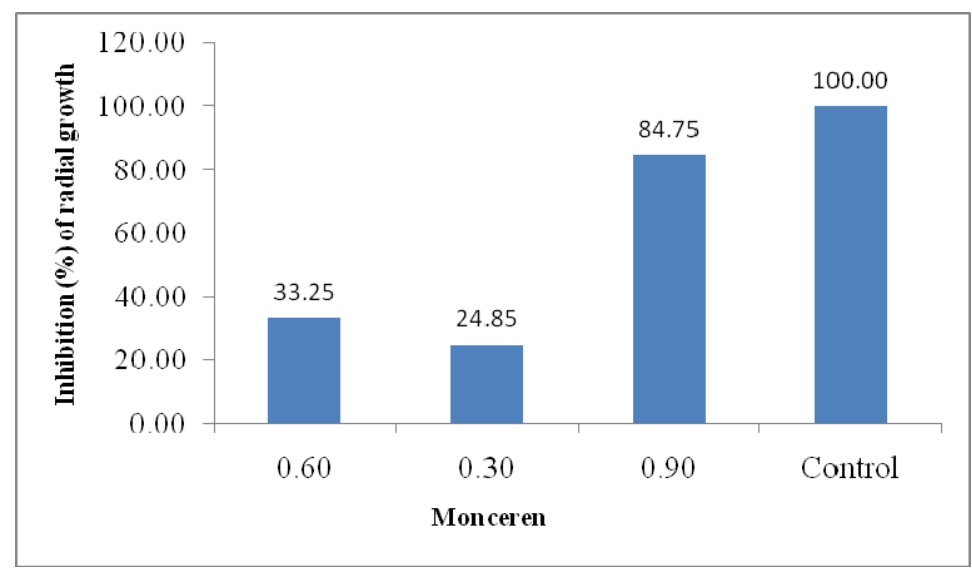

Figure 7. Effect of Monceren on mycelial growth of Rhizoctonia solani at different concentrations 


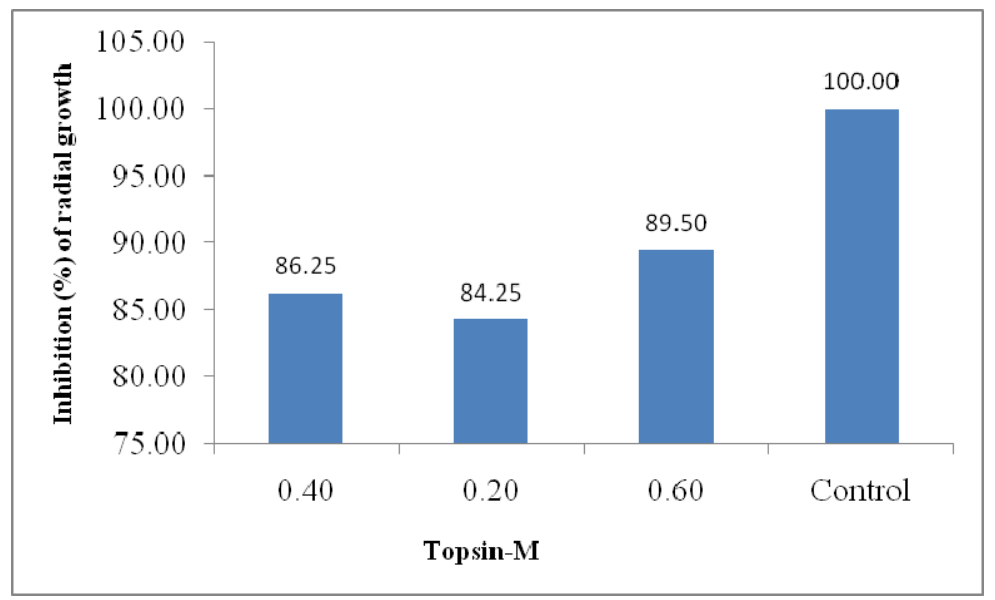

Figure 8. Effect of Topsin-M on mycelial growth of Rhizoctonia solani at different concentrations

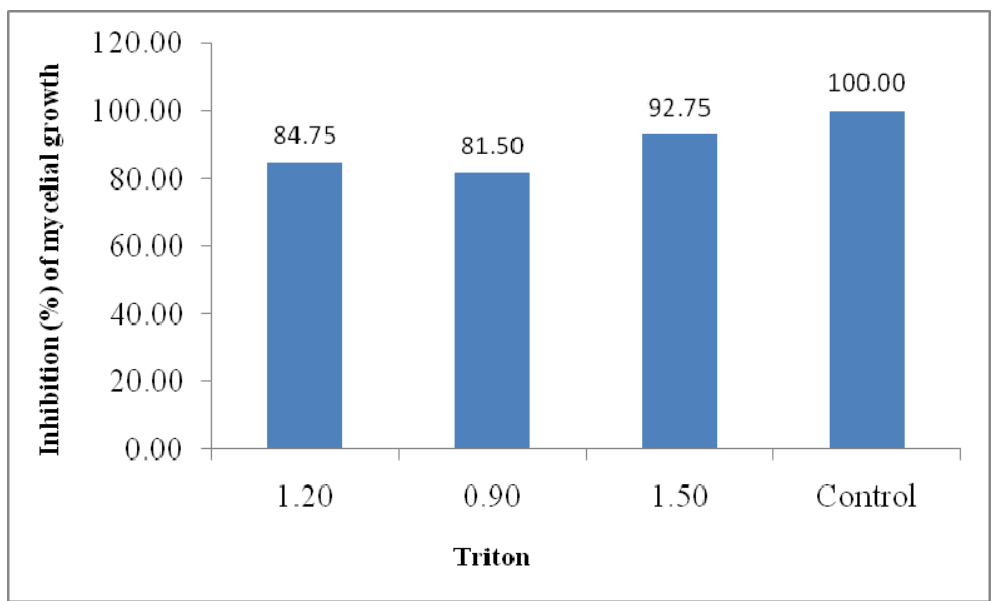

Figure 9. Effect of Triton on mycelial growth of Rhizoctonia solani at different concentrations

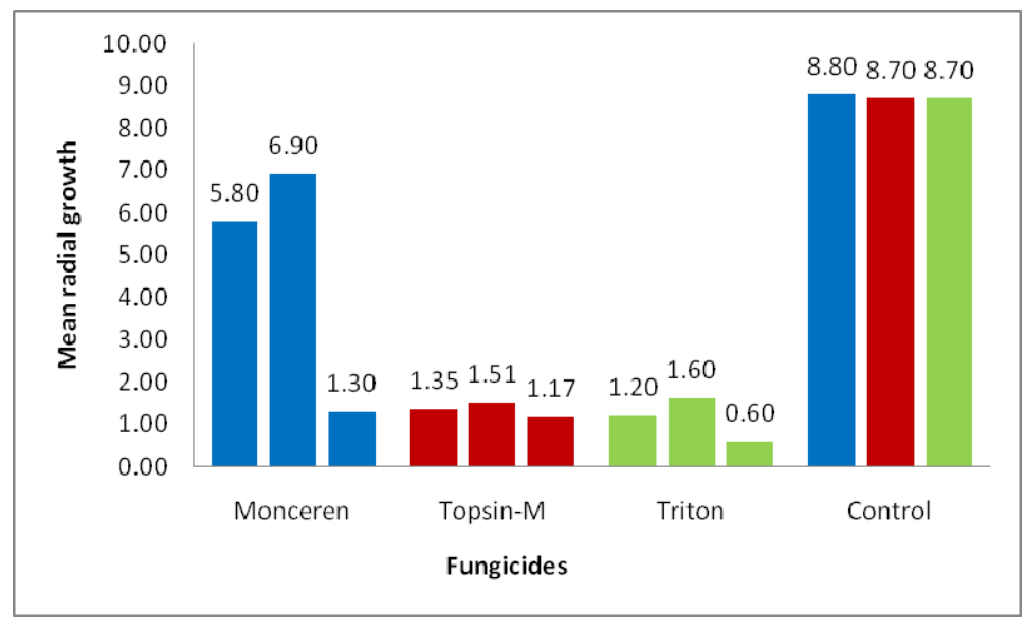

Figure 10. Mean mycelial growth of Rhizoctonia solani against different concentrations of fungicides

In biological control of Rhizoctonia solani, both accessions of Trichoderma spp. were found to be effective against the pathogen. Trichoderma harzianum showed maximum inhibition of $70 \%$ followed by the Trhicohderma viridae (66\%). The average growth of fungus in control plate was $8.8 \mathrm{~cm}$. 


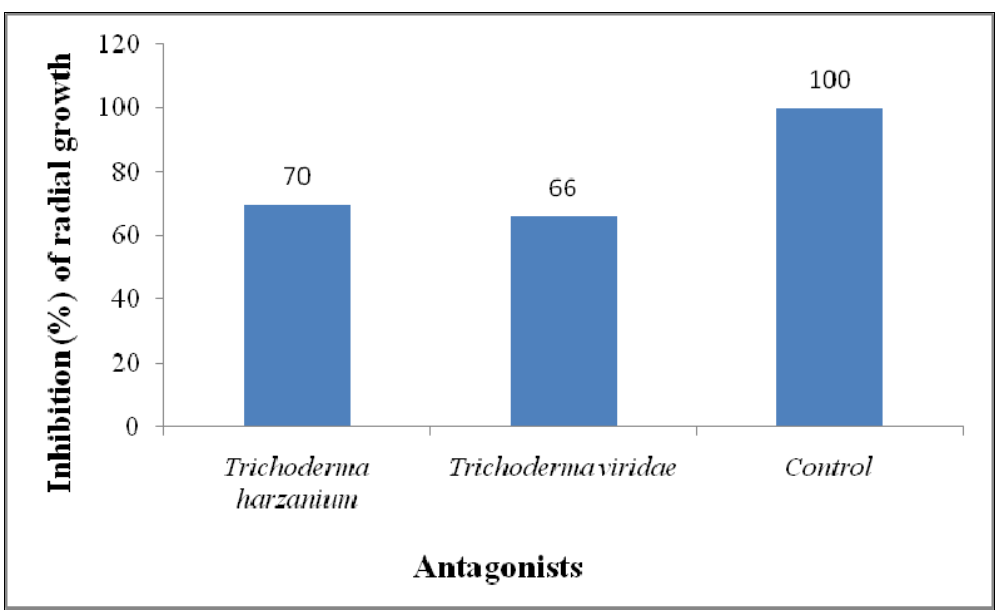

Figure 11. Effect of Trhichoderma spp. on mycelial growth of Rhizoctonia solani

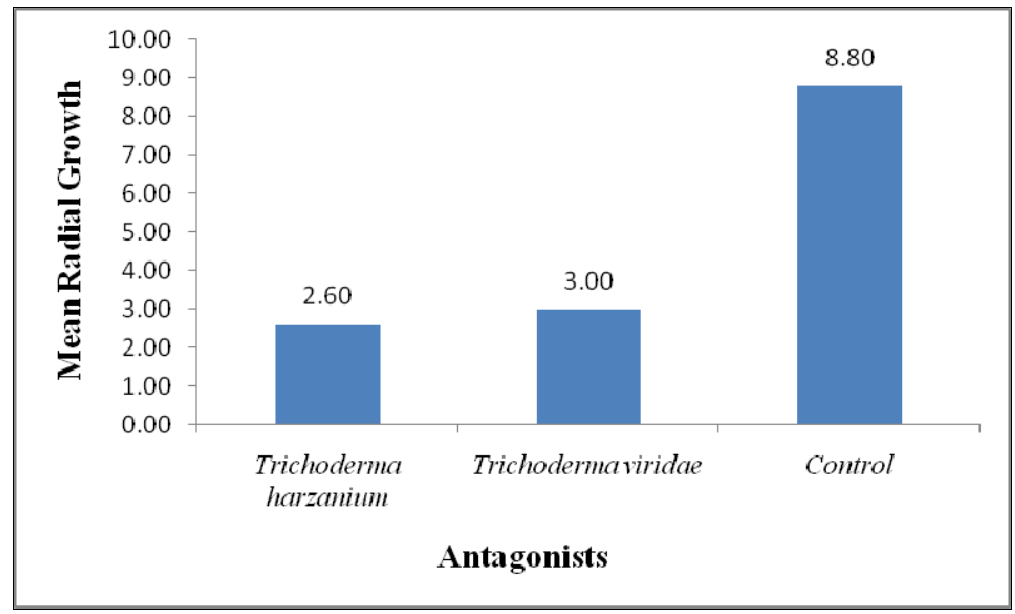

Figure 12. Mean mycelial growth of Rhizoctonia solani against the accessions of Trichoderma spp.

\section{Discussion}

Black scurf, caused by Rhizoctonia solani, is becoming more common and serious disease in the potato fields of Multan region; may inflict enormous losses to the production of potato crop with the occurrence of disease symptoms in the fields as black sclerotial masses on tuber surface and aerial tubers on foliar parts (Wharton et al., 2007), Rhizoctonia solani was isolated from the diseased potato tubers on potato dextrose agar medium and identified through microscopic characterization (Ritche et al., 2009). Disease incidence remained $70 \%$ whereas severity on $0-5$ rating scale remained 1.8 . Highest mean disease incidence and severity of $95 \%$ and 3.1 rating was found in Kotla Abdul-Fateh and Moaza Dhillun localities in Multan.

Rauf et al. (2007b) reported that black surf disease of potato caused by Rhizoctonia solani was a common fungal disease in all the eight potato production agro-ecological zones of Pakistan with highest mean disease incidence and severity of $65 \%$ and 2.95 rating respectively in Punjab Province. A total of $80 \%$ of potato crop is produced in Punjab in Pakistan (Rauf et al., 2007b), potato production is rigorous in the areas near cold stores and bazaars in the towns (Geddes et al., 1985). High prevalence of black scurf of potato in Punjab is due to the favorable climatic condition for the inoculum, extensive monocropping of cultivar Desiree, which is the highly susceptible to black scurf of potato, poor cultural practices and lack of quarantine measures for disease (Hooker, 1981; Khan \& Naumann, 1989). Low soil temperature, high moisture level together with zinc deficiency was the major factors favoring the development of disease in the surveyed locations (Ahmed et al., 1995; Thongbai et al., 1993). Potato crop cultivated without proper rotation tactics may lead to the encouragement of soil-borne diseases (Zanoni, 1991).

In vitro evaluation of chemical fungicides viz., pencycuron, validamycin, and thiophanate-methyl showed 
promising results at three different concentrations, validamycin at $1.5 \mathrm{ml}(\mathrm{v} / \mathrm{v})$ remained more effective in inhibiting $(92.75 \%)$ of radial growth of Rhizoctonia solani followed by thiophanate-methyl with $(86.25 \%)$ inhibition at $0.6 \mathrm{~g}(\mathrm{w} / \mathrm{v})$ and pencycuron at $0.9 \mathrm{ml}(\mathrm{v} / \mathrm{v})$ showed $(84.75 \%)$ inhibition. Our results are confirmatory with Idrees et al. (2009) who evaluated thiophanate methyl, copper oxychloride, and carbandazim, thiophanate methyl showed significant results. Similarly, Rauf et al. (2007a) evaluated various fungicides viz., pencycuron, mancozeb, and benlate against black scurf in field trials and reported pencycuron to be the best fungicide against the disease. The sclerotial viability of Rhizoctonia solani was greatly reduced by the treatment of potato seeds using pencycuron, Daconil and a dicarboximide fungicide i.e. Rovral (Wicks et al., 1995; Bajwa et al., 1998; Campion et al., 2003).

Management through fungicidal chemistries is only effective when the levels of initial inoculum were not high as the quantity of Rhizoctonia solani on tubers increases, the effectiveness of fungicides decreases (Tsror \& Peretz, 2005). In-vitro evaluation of bioagents viz., Trichoderma harzianum and Trichoderma viridae remained very significant against Rhizoctonia solani. Trichoderma harzianum showed prominent antagonism (70\%) against Rhizoctonia solani followed by Trichoderma viridae with (66\%) inhibition. Our results supported Joshi et al. (2010) who evaluated 62 isolates of Trichoderma spp. from samples of different rhizospheric soils and reported 80\% mycelial inhibition of Rhizoctonia solani. Similarly, Zhang and Wang (2012), Mustafa et al. (2009) examined antagonistic effect of different Trichoderma spp. isolates against Rhizoctonia solani by dual culture procedure, and reported Trichoderma longibrachiatum as best antagonist. Arora (2008) reported the treatment of Trichoderma viridae after seed dressing with boric acid (1.5\%) significantly minimized the black scurf disease on potato tubers. Evaluation of different isolates of Trichoderma spp. against Rhizocotnia solani, Fusarium oxysporum f.sp. phaseolin, and Drechslera tricirepentis, significantly controlled the mycelial growth of pathogen as reported by (Perello et al., 2003; Otadoh et al., 2011; Singh et al., 2008; Wilson et al., 2008).

\section{Conclusion}

In conclusion, the frightening situation of black scurf demands some multidimensional management tactics instantly to be taken for disease control and seed certification.

\section{Acknowledgements}

Grateful acknowledgments are due to Dr. Ummad ud din Umar, Assistant Professor, Department of Plant Pathology for his cooperation all the time during the research.

\section{References}

Ahmad, I., Iftikhar, S., Soomro, M. H., Hameed S., \& Khalid, S. (1995). Diseases of potato in Sindh, Pakistan during 1994 (p. 35). CDRI-PSPDP, PARC, Islamabad, Pakistan.

Ahmad, I., Iftikhar, S., Soomro, M. H., Khalid S., \& Munir, A. (1995). Diseases of potato in Northern Areas during 1992 (p. 38). CDRI-PSPDP, PARC, Islamabad, Pakistan.

Ahmad, I., Soomro, M. H., Khalid, S., Iftikhar, S., Munir, A., \& Burney, K. (1995). Recent distributional trends of potato diseases in Pakistan. National Seminar on Research and Development of Potato Production in Pakistan, April 23-25, NARC, PSPDP, PARC, Islamabad, Pakistan.

Anonymous. (2008). Agricultural Statistics of Pakistan. Govt. of Pakistan. Ministry of Food, Agriculture, and Livestock. Food, Agriculture \& Livestock Division (Economic Wing), Islamabad.

Anonymous. (2013). Agricultural Statistics of Pakistan. Govt. of Pakistan. Ministry of Food, Agriculture, and Livestock. Food, Agriculture \& Livestock Division (Economic Wing), Islamabad.

Arora, R. K. (2008). Management of black scurf of potato with the integrated use of Trichoderma viridae and boric acid. Potato Journal, 35(3\&4), 130-133.

Bajwa, K. M., Khan, T. Z., \& Bajwa, M. N. (1998). Effect of fungicides on Rhizoctonia solani the causing root of bottle gourd. Pak. J. Phytopathology, 19, 23-35.

Bhuiyan, M. K. A. (1994). Pathological and physiological study of Rhizoctonia oryzae causing rice bordered sheath spot disease (p. 39). A Ph.D. thesis submitted to the Department of Plant Pathology, Kynshu University, Fukuoka, Japan.

Campion, C., Chatot, C., Perraton, B., \& Andrivon, D. (2003). Anastomosis groups, pathogenicity and sensitivity to fungicides of Rhizoctonia solani isolates collected on potato crops in France. European Journal of Plant Pathology, 109, 983-992. http://dx.doi.org/10.1023/B:EJPP.0000003829.83671.8f

CIP. (2008). Potatoes and the environment. Fact sheet. CIP, Lima, Peru. 
Dhingra, O. D., \& Sinclair, J. B. (1985). Basic Plant Pathology Methods (pp. 132-163). CRC Press, Inc. Boca Raton, Florida.

Edington, L. V., Khew, K. L., \& Barron, G. I. (1971). Fungitoxic spectrum of benzimidazole compounds. Phytopathology, 61, 42-44. http://dx.doi.org/10.1094/Phyto-61-42

Geddes, A. M. W., Banaras, M., Khan, M. B., \& Farooq, K. (1985). Yield survey of autumn potato crop in Punjab plains. 1983/4.PSPDP/PARC, Islamabad.

Haq, Z., Nazli, H., \& Meilke, K. (2008). Implications of high food prices for poverty in Pakistan. Agricultural Economics, 39, 477-484. http://dx.doi.org/10.1111/j.1574-0862.2008.00353.x

Idrrees, M., Shaukat, A., Ayub, Niaz, M. Z., \& Qurban, A. (2009). Impact of seed dressing on soil borne potato tubers disease. Pak. J. Phytopathol, 21(1), 89-91.

Joshi, B. B., Bhatt, R. P., \& Bahukhandi, D. (2010). Antagonistic and plant growth activity of Trichoderma isolates of Western Himalayas. Journal of Environmental Biology, 31(6), 921-928.

Khan, R. A., Iftikhar, S., Rafi, A., Riaz, S., \& Ahmad, I. (1995). Distribution and incidence of tuber diseases of potato in Swat valley. National Seminar on Research and Development of Potato Production in Pakistan, April 23-25. 1995, NARC, PSPDP, PARC, Islamabad.

Kyritsis, P., \& Wale, S. J. (2002). Effect of mycelial inoculum level and cultivar susceptibility on Rhizoctonia solani development on potato stems and seed tubers. The-BCPC Conference Pests and disease (Volumes 1 and 2, pp. 761-764). Proceedings of an international conference held at Brighton Hilton Metropole Hotel, Brighton UL, 18-21 November 2002.

Morton, D. T., \& Stroube, N. H. (1955). Antagonistic and stimulatory effects of microorganism upon Sclerotium rolfsii. Phytopathology, 45, 419-420.

Mustafa, A., Khan, M. A., Inam-ul-Haq, M., Pervez, M. A., \& Umar, U. D. (2009). Usefulness of different culture media for In-Vitro Evaluation Of Trichoderma Spp. Against Seed-Borne Fungi Of Economic Importance. Pakistan Journal of Phytopathololy, 21(1), 83-88.

Otadoh, J. A., Okoth, S. A., Ochanda, J., \& Kahindi, J. P. (2011). Assessment of Trichoderma isolates for virulence efficacy on Fusarium oxysporum f. sp. phaseoli. Tropical and Subtropical Agroecosystems, 13, 99-107.

Parmeter, J. R. (1970). Taxonomy and nomenclature of the imperfect stage. In J. R. Parmeter Jr. (Ed.), Biology and Pathology of Rhizoctonia solani (pp. 7-19). Berkeley: University of California Press.

Perello, A., Monaco, C., Simond, M. R., Sisterna, M., \& Bello, G. D. (2003). Biocontrol efficacy of Trichoderma isolates for tan spot of wheat in Argentina. J. Crop Protect., 22, 1099-1106. http://dx.doi.org/10.1016/S0261-2194(03)00143-1

Rauf, C., Ahmad, I., \& Ashraf, M. (2007a). Management of Black Scurf Disease of Potato. Pak. J. Bot., 39(4), $1341-1352$.

Rauf, C., Ahmad, I., \& Ashraf, M. (2007b). Occurrence and distribution of black scurf of potato in Pakistan. Pak. J. Bot., 39(4), 1341-1352.

Ritchie, F., Bain, R. A., \& McQuilken, M. P. (2009). Effects of nutrient status, temperature and pH on mycelial growth, sclerotial production and germination of Rhizoctonia solani from potato. Journal of Plant Pathology, 91, 589-596.

Singh, V., Ranaware, A. M., \& Nimbkar, N. (2008). Bioefficacy of antagonists against root-rot fungus Macrophomina phaseolina of safflower. In Proceedings of 7th International Safflower Conference, Wagga, Australia.

Skidmore, A. M., \& Dickinson, C. M. (1976). Colony interactions and hyphal interferences between Septoria nodorum and phylloplane fungi. Transactions of the British Mycological Society, 66, 57 -64. http://dx.doi.org/10.1016/S0007-1536(76)80092-7

Sneh, B., Burpee, L., \& Ogoshi, A. (1991). Identification of Rhizoctonia species. APS Press. St. Paul, Minnesota, USA.

Sundar, A. R., Das, N. D., \& Krishnaveni, D. (1995). In vitro antagonism of Trichoderma spp. against two fungal pathogens of castor. Indian Journal of Plant Protection, 23, 152-155.

Thongbai, P., Hannam, R. J., Graham, R. D., \& Webb, M. J. (1993). Interaction between zinc nutritional status of 
cereal and Rhizoctoniaroot rot severity. Plant and Soil, 153, $207-214$. http://dx.doi.org/10.1007/BF00012994

Tredway, L. P., \& Burpee, L. L. (2001). Rhizoctonia diseases of turfgrass. The plant Health Instructor.

Tsror, L. (2010). Biology, Epidemiology and Management of Rhizoctonia solani on Potato. Journal of Phytopathology, 158, 649-658. http://dx.doi.org/10.1111/j.1439-0434.2010.01671.x

Tsror, L., \& Peretz-Alon, I. (2005). The influence of the inoculum source of Rhizoctonia solani on development of black scurf on potato. Journal of Phytopathology, 153(4). 240-244. http://dx.doi.org/10.1111/j.1439-0434.2005.00962.x

Wharton, P., Kirk, W., Berry, D., \& Snapp, S. (2007). Michigan Potato Diseases, Rhizoctonia stem canker and black scurf of potato. Extension Bulletin E-2994 New.

Wicks, T. J., Morgan, B., \& Hall, B. (1995). Chemical and biological control of Rhizoctonia solani on potato seed tubers. Australian Journal of Experimental Agriculture, 35, 661-664. http://dx.doi.org/10.1071/EA9950661

Wilson, P. S., \& Ketola, E. O., Ahvenniemi, P. M., Lehtonen, M. J., \& Valkonen, J. P. T. (2008). Dynamics of soilborne Rhizoctonia solani in the presence of Trichoderma harzianum: effects on stem canker, black scurf and progeny tubers of potato. Plant Pathology, 57, 152-161.

Zanoni, U. (1991). Potato Atlas and Compendium of Pakistan. PSPDP/PARC, Islamabad, Pakistan.

Zhang, R., \& Wang, D. (2012). Trichoderma spp. from rhizosphere soil and their antagonism against Fusarium sambucinum. African Journal of Biotechnology, 11(18), 4180-4186. http://dx.doi.org/10.5897/AJB11.3426

\section{Copyrights}

Copyright for this article is retained by the author(s), with first publication rights granted to the journal.

This is an open-access article distributed under the terms and conditions of the Creative Commons Attribution license (http://creativecommons.org/licenses/by/3.0/). 